Sains Malaysiana 49(5)(2020): 1121-1128

http://dx.doi.org/10.17576/jsm-2020-4905-17

\title{
Serological Detection of Anti-Leptospira Antibodies among Animal Caretakers, Dogs and Cats Housed in Animal Shelters in Peninsular Malaysia
}

(Pengesanan Serologi Antibodi Anti-Leptospira dalam Kalangan Penjaga Haiwan, Anjing dan Kucing yang Tinggal di Pusat Perlindungan Haiwan di Semenanjung Malaysia)

\author{
Abdul Rahman Alashraf, Siti Khairani-Bejo, Kuan Hua Khor, Rozanaliza Radzi, Puteri Azaziah \\ Megat Abdul Rani, Soon Heng Goh, Muhammad Sabri Abdul Rahman, Muhammad Azri Roslan, \\ ROSNAH ISMAIL \& SENG FONG LAU*
}

\begin{abstract}
Leptospirosis is a worldwide zoonotic disease caused by Leptospira spp. and it has emerged as one of the major public health issues worldwide. Despite extensive studies, information regarding leptospirosis in animal shelters in Malaysia is still scarce. The aim of this study was to determine anti-Leptospira antibodies and the most common circulating serogroups among humans and animals in animal shelters in west and south parts of Peninsular Malaysia. Blood samples were obtained from 58 humans, 127 dogs, and 47 cats, that were recruited from two shelters. All humans and dogs appeared healthy, except few cats showed clinical signs of mild feline upper respiratory disease. Microscopic Agglutination Test (MAT) was used to detect anti-Leptospira antibodies against 20 pathogenic serovars. Based on the cut-off antibody titre $\geq 1: 100$, the sero-detection of Leptospira spp. in human, dogs, and cats were as 8.62\%, 20.47\%, and $14.89 \%$, respectively. Serogroup Bataviae was found in human, dogs and cats, whereas Bataviae, Javanica, and Ballum were the common serogroups among dogs and cats. Anti-Leptospira antibodies titres were in the range from 1:100 to 1:200 in human and 1:100 to 1:400 in sheltered animals. Sero-detection studies of anti-Leptospira antibodies in shelters environment worldwide and regionally is necessary to increase the public health awareness and to understand the risk of this zoonotic disease. Furthermore, data regarding the predominant serogroups is needed in a local setting for further vaccination development studies. More studies are warranted to investigate the role of sheltered animals in leptospiral transmission in its environment.
\end{abstract}

Keywords: Bataviae; human; leptospirosis; MAT; shelter animals

\section{ABSTRAK}

Leptospirosis adalah penyakit zoonosis di seluruh dunia yang disebabkan oleh Leptospira spp. dan penyakit ini telah muncul sebagai salah satu isu utama kesihatan awam di seluruh dunia. Walaupun terdapat kajian yang luas mengenai leptospirosis, maklumat tentang leptospirosis di tempat perlindungan haiwan di Malaysia masih lagi terhad. Tujuan kajian ini adalah untuk menentukan antibodi anti-Leptospira dan juga mengenal pasti serokumpulan yang paling lazim ditemui dalam kalangan manusia dan haiwan di pusat perlindungan haiwan di bahagian barat dan selatan Semenanjung Malaysia. Sampel darah yang diambil daripada 58 orang manusia, 127 ekor anjing dan 47 ekor kucing telah direkrut dari dua pusat perlindungan haiwan. Kesemua manusia dan anjing yang direkrut kelihatan sihat, kecuali beberapa ekor kucing yang menunjukkan tanda-tanda klinikal ringan penyakit pernafasan atas felin. Ujian Aglutinasi Mikroskopik (MAT) digunakan untuk mengesan antibodi anti-Leptospira terhadap 20 serovar patogenik. Berdasarkan tahap titer antibodi $\geq 1: 100$, sero-pengesanan untuk Leptospira spp. pada manusia, anjing dan kucing masing-masing adalah sebanyak 8.62\%, 20.47\% dan 14.89\%. Serokumpulan Bataviae ditemui pada manusia, anjing dan kucing, manakala Bataviae, Javanica dan Ballum adalah serokumpulan yang lazim dalam kalangan anjing dan kucing. Titer antibodi anti-Leptospira yang direkodkan berada dalam lingkungan 1:100 hingga 1:200 untuk manusia dan 1:100 hingga 1:400 untuk haiwan yang terlindung. Kajian sero-pengesanan antibodi anti-Leptospira perlu dijalankan di persekitaran tempat perlindungan seluruh dunia dan serantau bagi meningkatkan kesedaran kesihatan orang awam dan juga memahami risiko penyakit zoonotik ini. Tambahan pula, data tentang serokumpulan yang dominan diperlukan dalam suasana setempat untuk kajian yang lebih lanjut seperti pembangunan vaksin. Lebih banyak kajian wajar dijalankan untuk mengkaji peranan haiwan terlindung dalam penyebaran leptospiral dan juga persekitarannya.

Kata kunci: Bataviae; leptospirosis; haiwan yang terlindung; manusia; MAT 


\section{INTRODUCTION}

Leptospirosis is a worldwide zoonotic disease caused by Leptospira spp., and it is endemic in tropical countries (Bharti et al. 2003; Guerra 2013). The exposure to Leptospira spp. has been reported in a wide range of mammalian species (Ko et al. 2009). Infected rats' urine is the main source of infection for both human and animals (Cosson et al. 2014; Hartskeerl \& Ellis 2011). The infection was speculated to have high endemicity in rural areas, but there is increasing number of cases and frequent outbreaks found in urban settings (Bharti et al. 2003). Leptospirosis has emerged as a public health issue worldwide and approximately half a million of human cases were reported annually, with more than 10\% mortality rate (Abiayi et al. 2015). In Malaysia, there is a marked increase of leptospirosis cases with the incidence rate of up to 15 cases per 100,000 population in human in 2013 (Benacer et al. 2016c). The clinical signs of leptospirosis in humans may vary, such as febrile, jaundice and renal failure (Bharti et al. 2003). In animals, the clinical signs can vary from none to mild among hostadapted-serovars (Adler \& Moctezuma 2009), whereas the clinical signs are more visible in infected animals by non-adapted-serovars and more frequently seen in juvenile animals (Birnbaum et al. 1998; Ellis 1994).

Leptospira spp. are transmitted to human through non-intact skin and mucosal membrane exposure to the infective source (including wounds, eyes, and skin). The role of companion animals including dogs and cats in the transmission of the disease is currently debatable, some studies have hypothesized that companion animals pose a significant role in the transmission of the disease (André-Fontaine 2006; Prescot et al. 2013; Wasiński \& Dutkiewicz 2013). It has been demonstrated that the dog plays a crucial role in disease transmission as a main source for human leptospirosis in Russia (Wasiński \& Dutkiewicz 2013). Recently, cats has been shown to have high susceptibility to the infection (Hartmann et al. 2013). Leptospiral pathogenic DNA was found in cats' urine (Chan et al. 2014; Weis et al. 2017). Therefore, the role of cats in leptospiral transmission to human population remains crucial to be investigated.

The common serovars circulating among mammals vary depending on the geographic distribution, wild animals exposure and domestic reservoirs, such as serovars; Icterohaemorrhagiae in Europe and Lai in southeast Asia (Levett 2001). Serovars Icterohaemorrhagiae, Canicola, Ballum, Grippotyphosa, and Sejroe were reported in clinically infected dogs with Leptospira spp. (Sykes et al. 2011). Whereas in cats, a wide range of serovars such as Canicola, Icterohaemorrhagiae, Pomona, Hardjo, Autumnalis and Ballum were found serologically (Hartmann et al. 2013; Mylonakis et al. 2005; Rodriguez et al. 2014). In Malaysia, approximately 37 reported serovars in human and animals, mostly isolated from rats. Thirteen serogroups are circulating commonly among human and domestic animals (Bahaman \& Ibrahim 1988; Benacer et al. 2017; Rafizah et al. 2013). Serogroup Bataviae has been reported in human, dogs, cats, and rats in many recent studies (Alashraf et al. 2019; Benacer et al. 2016a; Khor et al. 2016; Lau et al. 2017; Rafizah et al. 2013; Shafei et al. 2012).

Leptospira infection among shelter workers and sheltered animal population seems to be under-reported. In Malaysia, a number of animal shelters are running under insufficient financial support with lack of education against zoonotic diseases. In comparison to the general population, humans and animals in shelters environment have a higher chance to be exposed to zoonoses diseases including leptospirosis. The aims of this study are to serodetect Leptospira exposure and to determine the common circulating serogroups among caretakers and sheltered dogs and cats in two shelters that are located in two different environments (urban and rural).

\section{MATERIALS AND METHODS}

ETHICAL APPROVAL

This study was approved by Research Ethics Committee (UKMPPI/111/8/JEP-2016-494) and Universiti Putra Malaysia Institutional Animal Care and Use Committees (UPM/IACUC/AUP-R050/2017 and UPM/ IACUC/AUP-R091/2016).

\section{BLOOD SAMPLING}

After the consent from the shelter managers was taken, blood was collected universally from humans and randomly from animals. Shelter caretakers' blood samples were collected by medical doctors from cephalic vein. Dogs and cats' blood was collected by veterinarians from jugular vein. All blood samples were almost at 3 $\mathrm{mL}$ of volume and kept in plain tubes to be maintained at $4{ }^{\circ} \mathrm{C}$ for the transportation to Bacteriology Laboratory, Universiti Putra Malaysia. Blood tubes were centrifuged for five min at $5000 \mathrm{rpm}$ and the sera were stored at -80 ${ }^{\circ} \mathrm{C}$ for further analysis using MAT test.

\section{MICROSCOPIC AGGLUTINATION TEST (MAT)}

Each blood serum was tested against 20 leptospiral serovars antigens (Table 1). All serovars were subcultured in Ellinghausen-McCullough-Johnson-Harris (EMJH) media and maintained for 7-10 days. The live antigens were checked under the dark field microscopic before being used.

Sera were aliquoted along with negative control (leptospires culture with no sera is added) in sterile microtiter plates. The sera were tested at serial dilution titres from 1:50 till 1:1600. Ninety six (96) $\mu \mathrm{L}$ of neutral PBS and $4 \mu \mathrm{L}$ serum were distributed into the first wells and followed by a two-fold dilution, then $50 \mu \mathrm{L}$ antigen cultures at a density of $1 \times 10^{8}$ cell $/ \mathrm{mL}$ were pipetted into each well. The loaded flat-bottomed microtiter 
plates were incubated for two hours at $30{ }^{\circ} \mathrm{C}$. Dark-field microscopic examination was carried out per each well. The serum was positive upon $50 \%$ agglutination with no free leptospires. A cut-off antibody titre of $\geq 1: 100$ was used following previous leptospirosis studies in human, dogs, and cats (Azócar-Aedo et al. 2014; Miotto et al. 2018; Pratt et al. 2017; Shafei et al. 2012).

TABLE 1. Leptospira serovars used in this study

\begin{tabular}{|c|c|c|c|}
\hline Species & Serogroup & Serovar & Strain \\
\hline \multirow[t]{13}{*}{ L. interrogans } & Icterohaemorrhagiae & Icterohaemorrhagiae & RGA \\
\hline & Pyrogenes & Pyrogenesj & Salinem \\
\hline & Canicola & Canicola & Hond Utrecht IV \\
\hline & Hebdomadis & Hebdomadis & Hebdomadis \\
\hline & Pomona & Pomona & Pomona \\
\hline & Bataviae & Bataviae & Swart \\
\hline & Sejroe & Hardjo & Hardjoprajitno \\
\hline & Australis & Australis & Ballico \\
\hline & Icterohaemorrhagiae & Lai & Lai \\
\hline & Autumnalis & Autumnalis & Akiyami A \\
\hline & Icterohaemorrhagiae & Copenhageni & Fiocruz L1-130 \\
\hline & Celledoni & Celledoni & Celledoni \\
\hline & Djasiman & Djasiman & Djasiman \\
\hline \multirow[t]{4}{*}{ L. borgpetersenii } & Ballum & Ballum & Mus 127 \\
\hline & Hardjobovis & Hardjobovis & Strain 11 \\
\hline & Javanica & Javanica & Veldrat Bataviaee 46 \\
\hline & Tarassovi & Tarassovi & Perepelitsin \\
\hline L. kirschneri & Grippotyphosa & Grippotyphosa & Moskva v \\
\hline \multirow[t]{2}{*}{ L. kmetyi } & Cynopteri & Cynopteri & $3522 \mathrm{c}$ \\
\hline & Tarassovi & Malaysia & Bejo-iso9 \\
\hline
\end{tabular}

STATISTICAL ANALYSIS

Descriptive statistic was applied based on confidence level as $95 \%$ and MedCalc ${ }^{\circledR}$ software was used for the statistical calculations.

\section{RESULTS}

\section{DEMOGRAPHIC}

In this study, blood samples of 58 humans, 127 dogs, and 47 cats were collected from two shelters (A and B). All human and dogs appeared healthy upon sampling, whereas, some of the cats in shelter B showed mild feline upper respiratory disease. The humans age range was between 30 and 40 years old, whereas only adult cats and dogs were recruited for sampling. All the dogs were not vaccinated against Leptospira spp. prior to the blood collection.

Shelter A was located in a rural area in southern part of Malaysia, with a population of 42 caretakers, 3000 dogs and 50 cats. In this shelter, a total of 125 blood samples were collected; 42 from humans, 66 from dogs and 17 from cats. This shelter was located within an oil palm plantation and surrounded by swamps. The workers' resting area was located at the centre of the dog kennel and all the dogs were kept in different pens 
with concrete flooring (Figure 1(A)). Cats were kept separately in rooms with wooden floor just outside of the dog kennel (Figure 1(B)). Most of the caretakers are locals ( $\sim 10 \%$ foreigners) that had a low education level (primary school), the awareness level was poor upon interviewing about leptospirosis, as observed on-site poor hygiene practice was noticed with improper hand cleaning after handling animals or their foods.

Meanwhile, shelter B was located in the middle of the city, surrounded by a residential area. This shelter had
20 caretakers, 300 dogs and approximately 100 cats. In this shelter, a total of 107 blood samples were collected; 16 humans were recruited, 61 dogs and 30 cats. Dogs were grouped in different pens next to the cats' area. Both cats and dogs were housed in metal cages with open access to a common area with humans (Figure 1(C) and 1(D)). Caretakers in this shelter had higher education level than in shelter A and were observed to practice a good hygiene habits and self-cleaning.
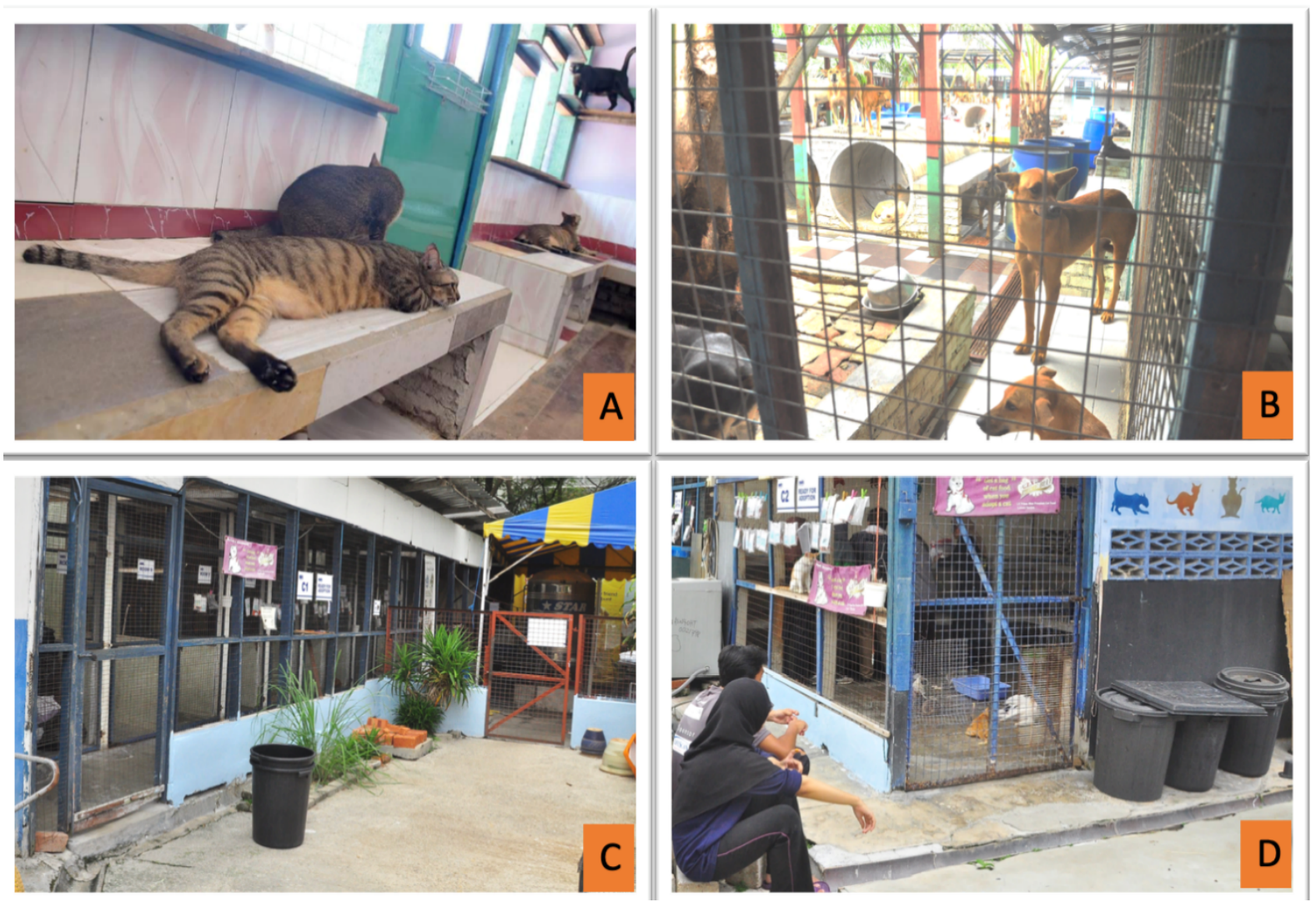

FIGURE 1. (a,b) Shelter A was located at a rural area and surrounded by oil palm plantation. Dogs in shelter A were housed in the concrete area separated from cats which were housed in rooms with wooden flooring. $(\mathrm{c}, \mathrm{d})$ Shelter B was located at an urban area and surrounded by residential. Cats were housed in metal cages next to the dog kennels

\section{MICROSCOPIC AGGLUTINATION TEST (MAT)}

The titre $\geq 1: 100$ was used as cut-off point for humans, dogs, and cats. In total, $8.62 \%$ humans had antibodies towards Leptospira spp. for three sero groups namely, Bataviae, Hebdomadis, and Canicola (shelter $\mathrm{A}=9.52 \%$ (4/42); shelter $B=6.25 \%(1 / 16)$ ). In dogs, $20.47 \%$ were seropositive (shelter $\mathrm{A}=7.57 \%(5 / 66)$; shelter $\mathrm{B}=34.43 \%$ $(21 / 61)$ ), and $14.89 \%$ in cats were seropositive for antiLeptospira antibodies (shelter $\mathrm{A}=5.88 \%(1 / 17)$; shelter $\mathrm{B}=20 \%(6 / 30))$ (Table 2).
In total, eight serogroups were detected in human, dogs, and cats (Table 3). Serogroup Bataviae was found in both human and shelter animals. Three serogroups were common among dogs and cats, namely, Bataviae, Javanica, and Ballum with a titre range of 1:100 to 1:400. Canicola was found in both human and dogs at the titre of 1:100, meanwhile, Hebdomadis was detected only in human with a titre range from 1:100 to 1:200, whereas Icterohaemorrhagiae, Lai and Australis were observed only in dogs with a titre range from 1:100 to 1:400. 
TABLE 2. Summary of the results of MAT for shelter A and B for humans, dogs and cats

\begin{tabular}{cccccc}
\hline Samples & Shelter A & $\begin{array}{c}\text { Positive } \\
\text { number (\%) }\end{array}$ & Shelter B & $\begin{array}{c}\text { Positive } \\
\text { number (\%) }\end{array}$ & $\begin{array}{c}\text { Total positive } \\
\text { number }(\%)\end{array}$ \\
\hline Humans $(\mathrm{n}=58)$ & 42 & $4(9.52 \%)$ & 16 & $1(6.25 \%)$ & $5(8.62 \%)$ \\
Dogs $(\mathrm{n}=127)$ & 66 & $5(7.57 \%)$ & 61 & $21(34.43 \%)$ & $26(20.47 \%)$ \\
Cats $(\mathrm{n}=47)$ & 17 & $1(5.88 \%)$ & 30 & $6(20 \%)$ & $7(14.89 \%)$ \\
\hline
\end{tabular}

TABLE 3. Result of titres of the detected serovars in shelter A and B for humans, dogs and cats

\begin{tabular}{|c|c|c|c|c|c|c|c|c|c|}
\hline & \multicolumn{3}{|c|}{ Human } & \multicolumn{3}{|c|}{ Dogs } & \multicolumn{3}{|c|}{ Cats } \\
\hline & $\begin{array}{c}\text { Positive } \\
\text { number (\%) }\end{array}$ & Titre & Shelter & $\begin{array}{c}\text { Positive } \\
\text { number (\%) }\end{array}$ & Titre & Shelter & $\begin{array}{c}\text { Positive } \\
\text { number (\%) }\end{array}$ & Titre & Shelter \\
\hline Bataviae & $2(4.16 \%)$ & 1:100\&1:200 & $\mathrm{A}, \mathrm{B}$ & $3(2.36 \%)$ & $1: 100-1: 400$ & B & $1(2.12 \%)$ & $1: 400$ & B \\
\hline Hebdomadis & *3 (5.26\%) & $1: 100-1: 200$ & A & ND & ND & ND & ND & ND & ND \\
\hline Ballum & ND & ND & ND & $+11(8.66 \%)$ & $1: 100-1: 400$ & $+\mathrm{B}$ & $4(8.51 \%)$ & $1: 100-1: 400$ & $\mathrm{~A}, \mathrm{~B}$ \\
\hline Javanica & ND & ND & ND & $2(1.57 \%)$ & 1:100\&1:400 & A & $2(4.25 \%)$ & 1:100\&1:400 & B \\
\hline Lai & ND & ND & ND & $+3(2.36 \%)$ & $1: 100-1: 400$ & B & ND & ND & ND \\
\hline Canicola & *1 $(2.08 \%)$ & 1:100 & $\mathrm{A}, \mathrm{B}$ & $1(0.78 \%)$ & $1: 100$ & $\mathrm{~A}, \mathrm{~B}$ & ND & ND & ND \\
\hline $\begin{array}{l}\text { Icterohae- } \\
\text { morrhagiae }\end{array}$ & ND & ND & ND & $+9(7.08 \%)$ & $1: 100-1: 200$ & $\mathrm{~A}, \mathrm{~B}$ & ND & ND & ND \\
\hline Australis & ND & ND & ND & $1(0.78 \%)$ & $1: 100$ & A & ND & ND & ND \\
\hline
\end{tabular}

ND: Not detected. *One human serum in shelter A showed positive reactions to both Canicola and Hebdomadis, the perspective infective serogroup showed a higher titre. +Four dogs in shelter B had positive sera for Icterohaemorrhagiae and either Lai or Ballum, the perspective infective serogroup showed a higher titre

\section{DISCUSSION}

The tropical climate of Malaysia favours the survivability of Leptospira spp. and the infection was reported in humans and a wide range of animals (domestic and wild animals) (Bahaman \& Ibrahim 1988; Garba et al. 2017). However, the information about leptospirosis in animals shelters in Malaysia remains scarce. Therefore, this study aimed to determine Leptospira spp. exposure among shelter caretakers, dogs and cats in two different shelters and to identify the common circulating serogroups among human and shelter animals.

Based on the cut-off point of $\geq 1: 100$, the results of this study showed that both humans and shelter animals had antibodies towards Leptospira with seropositivity of $8.62 \%$ in human, $20.47 \%$ in dogs, and $14.89 \%$ in cats. The sero-detection of Leptospira spp. infection in humans in this study was lower compared to a study by Shafei et al. (2012), that reported a sero-detection of $24 \%$ among 296 municipal workers in North-eastern part of Malaysia, this might be due to the occupation of the service workers that had a close contact with the contaminated garbage. Nevertheless, the findings of the present study reflect a risk of leptospirosis exposure to human in the shelters ecosystem in Malaysia.

In our study, two serogroups were found in humans namely, Bataviae and Hebdomadis. These serogroups are highly virulent in humans and were responsible for febrile and acute jaundice in a number of countries such as Indonesia, Lao PDR, Socialist Republic of Vietnam, and Cambodia (Laras et al. 2002). More recently, Bataviae was reported with a fatality rate as high as $10.5 \%$ in Indonesia (Benacer et al. 2016c; Hartskeel 2002). In Mayotte, Hebdomadis was the most common circulating serovar that was identified in $70 \%$ of 198 acute leptospiral hospitalized patients (Bourhy et al. 2012). However, upon sampling, the screened human appeared to be clinical-free, though the sero-detection of Leptospira spp. in this study might be translated as previous exposure or asymptomatic leptospirosis (Levett 2001). The presumptive diagnosis based on the serological-MAT can be defined with a four-fold rise in the sera titration, however, even a single antibody titre of $\geq 1: 100$ is likely a reflection of exposure (Budihal \& Perwez 2014). Even though no clinical signs were observed in human upon sampling, it should be mentioned that the clinical signs of leptospirosis can mimic other 
infectious disease, for example in a recent study 5\%-69\% of non-malarial fever cases were undifferentiated with leptospirosis (Costa et al. 2015). Moreover, a concurrent infection was found in one human serum that showed antibodies against Canicola at tire of 1:100 and against Hebdomadis at titre of 1:200. This would indicate an exposure to leptospirosis by more than one serovar in humans. Canicola has not been reported to crossreact with Hebdomadis and is among the first reported leptospires in humans (Lawson \& Michna 1966).

In this study, the sero-detection in human samples was higher in the rural shelter A $(9.52 \%$ (4/42)) compared to shelter B $(6.25 \%(1 / 16))$ where located in an urban area. Although there is no significant difference between the two sero-detections, the good personal hygiene is known as the main pillar in primary prevention and a main challenge against leptospirosis (Wasiński \& Dutkiewicz 2013). During samples collection, the workers in shelter A had an improper hygiene practice which was observed with no handwashing after close contact with the animals or after preparing and/or refilling the animals food. Whereas in shelter B, the caretakers had better self-hygiene practice that was observed with proper handwashing at stations located outside the animals kennels. Public health professionals need to put a leap forward in promoting such prevention through easy age and educational backgrounds-related techniques, such as run campaigns against leptospirosis that focus on hygienic habits after handling animals (including care of clothing and handwashing). As this is a preliminary study, a robust sample size is warranted for future research to analyse the risk factors of leptospirosis transmission in shelters ecosystem in Malaysia.

In this study, sheltered dogs showed higher seropositivity in comparison to previous studies, which reported 3.1\% (3/96) and 3.8\% (3/80) of sero-detection among dogs in Malaysia (Khor et al. 2016; Lau et al. 2017). The differences in the results might be due to the varied sample sizes and the geographical locations. The sero-detection found in cats in this study was $14.89 \%$ and supports previous studies that reported leptospirosis exposure as high as $10 \%(n=68)$ in cats and $18 \%(n=110)$ more recently in shelter cats (Alashraf et al. 2019; Gordon-Smith et al. 1961). In shelter B, the sero-detection in both dogs and cats was higher in comparison to shelter A (Table 2). This might be due to the fact that in shelter B, the animals cages had an open access that could allow the entrance of infected rats and contaminated water with Leptospira spp., which represents a high risk of exposure especially after heavy rainfall. That fact is supported by a recent Malaysian's study found that dogs in urban area were more vulnerable towards the infection than in rural area, due to the abundance of rats in the urban areas as a result of urbanisation (Benacer et al. 2017), in addition to a high Leptospira spp. infection was reported in rats sampled in urban area near by shelter B (Al Kattan et al. 2017). Moreover, the access of the animals to a common area in shelter B might therefore participate in increasing the chance of the transmission among cats and dogs, which was resulted in a higher detection in animals in comparison to shelter A.

Even though MAT is the gold standard for leptospirosis serological detection, but it has some limitations. Anti-Leptospira spp. antibodies are usually detectable on eight to ten days onwards after the onset of symptoms in clinical cases (Levett 2001; Ooteman et al. 2006). PCR is the test of choice for acute leptospirosis detection. Hence, in this study, seropositivity might be due to either previous exposure or current infection. With the low sensitivity of MAT and uncertain infection stage, we cannot rule out the potentiality of higher prevalence in one shelter or species due to the possibilities of a false negative result (Budihal \& Perwez 2014). AntiLeptospira antibodies have been serologically detected in human and dogs from different locations across the Peninsular of Malaysia and nevertheless, Bataviae serogroup seems to be the predominantly found serogroup (Al Kattan et al. 2017; Benacer et al. 2016a; Khor et al. 2016; Lau et al. 2017; Rafizah et al. 2013; Shafei et al. 2012). Interestingly in this study, serogroup Bataviae was the mutual serogroups in human, dogs and cats as well. The frequent detections of Bataviae in a number of studies among various hosts, could be an indicator of an endemicity of this serovar in Malaysia. While the other two serogroups namely, Ballum and Javanica were common in dogs and cats only in this study.

There is a succession of factors that cannot be separated between human and sheltered animals based on their exposure to the potential source of infection in the same environment. Poor hygiene practice and cage cleaning management often may lead to the attraction of rodents, which are prey to cats and sometimes dogs (Sykes et al. 2011). Hence, subsequently contaminated environment or infected animals could pose a high risk to both human and other animals (Schuller et al. 2015; Sykes et al. 2011). The inappropriate personal fittings and careless self-protection during daily work in kennels might expose the human' mucous membranes or wounded skin to Leptospira spp. where the poor hygiene was found to play a role in the transmission among animals shelters (Catley 2009). The Leptospira spp. can also be transmitted by asymptomatically infected animals, even with good hygiene and absence of rats since these animals are in direct contact with human (Arbour et al. 2012; Rojas et al. 2010).

Icterohaemorrhagiae was the most encountered serogroup in dogs in this study, which is contrary to recent published study on sheltered dogs (Khor et al. 2016). Icterohaemorrhagiae bacterin is added in most of the commercial inactivated leptospirosis vaccine for dogs (Klaasen et al. 2003), in which the emergence of this serogroup could be due to the absence of vaccination in the sampled dogs. In the present study, some serogroups found in cats and dogs, such as Javanica and Ballum but not in human. These serogroups should not be disregarded since low antibodies titres in animals is a risk of contamination (de Vries et al. 2014). The high detected titres to a wide range of serogroups, would 
pose a greater risk to contaminate the environment and to infect human as well. In terms of leptospirosis preventions, vaccinations in sheltered animals and application of rodenticide are recommended (Sharma \& Yodav 2008). Inclusion of the most common serovar in the local setting in the vaccine should be considered as currently most of the found serogroups in dogs are not included in vaccines serovars (Sessions \& Greene 2004). Finally, creation of awareness against the proper hygiene practice and recognition of clinical signs caused by leptospirosis among the workers or volunteers is of crucial importance as they are in close contact with sheltered animals on daily basis.

\section{CONCLUSION}

This study found low sero-positivity in human but higher in shelters' dogs and cats. It is the first report of mutual serogroup found among human, dogs and cats in the same environment. Both cats and dogs were sharing three serogroups with high titres ranges. All seropositive human, dogs, and cats were asymptomatic upon sampling. Regional studies with bigger samples in Malaysia are warranted in order to investigate the seroprevalence and educate the workers in shelters in terms of zoonotic diseases transmission and its preventive ways at the same time.

\section{ACKNOWLEDGEMENTS}

The authors would like to thank the Bacteriology Lab of the Faculty of Veterinary Medicine, Universiti Putra Malaysia for their assistance in processing the samples and for their technical assistance.

\section{REFERENCES}

Abiayi, E.A., Inabo, H.I., Jatau, E.D., Makinde, A.A., Sar, T.T. \& Dangeri, M.A. 2015. Occurrence of leptospirae antibodies in abattoir workers in parts of North Central Nigeria. Research Journal of Immunology 8(1): 27-34.

Adler, B. \& de la Peña Moctezuma, A. 2009. Leptospira and leptospirosis. Journal of Veterinary Microbiology Journal 140(3-4): 287-296.

Al Kattan, G., Bahaman, A.R., Bejo, S.K., Zakaria, Z. \& Garba, B. 2017. Serological and molecular prevalence of leptospira infection in rat populations in Kuala Lumpur. Australian Journal of Basic and Applied Sciences 11: 62-72.

Alashraf, A.R., Lau, S.F., Khor, K.H., Khairani-Bejo, S., Bahaman, A.R., Roslan, M.A. \& Radzi, R. 2019. Serological detection of anti-leptospira antibodies in shelter cats in Malaysia. Topics in Companion Animal Medicine 34: 10-13.

Arbour, J., Blais, M.C., Carioto, L. \& Sylvestre, D. 2012. Clinical leptospirosis in three cats (2001-2009). Journal of the American Animal Hospital Association 48(4): 256-260.

Bahaman, A.R. \& Ibrahim, A.L. 1988. A review of leptospirosis in Malaysia. Veterinary Research Communications 12: 179-189.

Benacer, D., Thong, K.L., Ooi, P.T., Souris, M., Lewis, J.W., Ahmed, A.A. \& Mohd Zain, S.N. 2017. Serological and molecular identification of Leptospira spp. in swine and stray dogs from Malaysia. Tropical Biomedicine 34(1): 89-97.

Benacer, D., Mohd Zain, S.N., Sim, S.Z., Mohd Khalid, M.K.N., Galloway, R.L., Souris, M. \& Thong, K.L. 2016a.
Determination of Leptospira borgpetersenii serovar Javanica and Leptospira interrogans serovar Bataviae as the persistent Leptospira serovars circulating in the urban rat populations in Peninsular Malaysia. Parasites and Vectors 9(1): 117.

Benacer, D., Thong, K.L., Min, N.C., Verasahib, K. Bin., Galloway, R.L., Hartskeerl, R.A., Souris, M. \& Zain, S.N.M. 2016b. Epidemiology of human leptospirosis in Malaysia, 2004-2012. Acta Tropica 157: 162-168.

Benacer, D., Thong, K.L., Verasahib, K. Bin., Galloway, R.L., Hartskeerl, R.A., Lewis, J.W. \& Mohd Zain, S.N. 2016c. Human leptospirosis in Malaysia: Reviewing the challenges after 8 decades (1925-2012). Asia-Pacific Journal of Public Health 28: 290-302.

Bharti, A.R., Nally, J.E., Ricaldi, J.N., Matthias, M.A., Diaz, M.M., Lovett, M.A. \& Vinetz, J.M. 2003. Reviews leptospirosis: A zoonotic disease of global importance. The Lancet. Infectious Diseases 3: 757-771.

Birnbaum, N., Barr, S.C., Center, S.A., Schermerhorn, T., Randolph, J.F. \& Simpson, K.W. 1998. Naturally acquired leptospirosis in 36 dogs: Serological and clinicopathological features. The Journal of Small Animal Practice 39(5): 231-236.

Bourhy, P., Collet, L., Lernout, T., Zinini, F., Hartskeerl, R.A., van Der Linden, H. \& Giry, C. 2012. Human Leptospira isolates circulating in Mayotte (Indian Ocean) have unique serological and molecular features. Journal of Clinical Microbiology 50(2): 307-311.

Budihal, S.V. \& Perwez, K. 2014. Leptospirosis diagnosis: Competancy of various laboratory tests. Journal of Clinical and Diagnostic Research 8(1): 199-202.

Catley, J.M. 2009. The prevalence of leptospira serovars causing infections in dogs in South Africa. Masters Theses, University of Pretoria, South Africa (Unpublished).

Chan, K.W., Hsu, Y.H., Hu, W.L., Pan, M.J., Lai, J.M., Huang, K.C. \& Chou, S.J. 2014. Serological and PCR detection of feline Leptospira in Southern Taiwan. Vector Borne and Zoonotic Diseases 14(1): 118-123.

Cosson, J.F., Picardeau, M., Mielcarek, M., Tatard, C., Chaval, Y., Suputtamongkol, Y. \& Morand, S. 2014. Epidemiology of Leptospira transmitted by rodents in Southeast Asia. PLoS Neglected Tropical Diseases 8(6): e2902.

Costa, F., Hagan, J.E., Calcagno, J., Kane, M., Torgerson, P., Martinez-Silveira, M.S. \& Ko, A.I. 2015. Global morbidity and mortality of leptospirosis: A systematic review. PLoS Neglected Tropical Diseases https://doi.org/10.1371/journal. pntd.0003898.

de Vries, S.G., Visser, B.J., Nagel, I.M., Goris, M.G.A., Hartskeerl, R.A. \& Grobusch, M.P. 2014. Leptospirosis in Sub-Saharan Africa: A systematic review. International Journal of Infectious Diseases 28: 47-64.

Ellis, W.A. 1994. Leptospirosis as a cause of reproductive failure. Veterinary Clinics of North America: Food Animal Practice 10(3): 463-478.

Garba, B., Bahaman, A.R., Khairani-Bejo, S., Zakaria, Z. \& Mutalib, A.R. 2017. Retrospective study of leptospirosis in Malaysia. EcoHealth 14(2): 389-398.

Hartmann, K., Egberink, H., Pennisi, M.G., Lloret, A., Addie, D., Belák, S. \& Horzinek, M.C. 2013. Leptospira species infection in cats: $\mathrm{ABCD}$ guidelines on prevention and management. Journal of Feline Medicine and Surgery 15(7): 576-581.

Hartskeel, R.A. 2002. Report of the Leptospirosis Outbreak in Indonesia, 2002. WHO/FAO/OIE/RIVM Leptospirosis Reference Centre, KIT Biomedical Research, Amsterdam. 
Report submitted to WHO South East Regional Office.

Hartskeerl, R.A. \& Ellis, W.A. 2011. Emergence, control and re-emerging leptospirosis: Dynamics of infection in the changing world. Clinical Microbiology and Infection 17(4): 494-501.

Khor, K.H., Tan, W.X., Lau, S.F., Mohd, A.R., Rozanaliza, R., Siti, K.B. \& Abdul, R.B. 2016. Seroprevalence and molecular detection of leptospirosis from a dog shelter. Tropical Biomedicine 33(2): 276-284.

Klaasen, H.L.B.M., Molkenboer, M.J.C.H., Vrijenhoek, M.P. \& Kaashoek, M.J. 2003. Duration of immunity in dogs vaccinated against leptospirosis with a bivalent inactivated vaccine. Veterinary Microbiology 95(1): 121-132.

Ko, A.I., Goarant, C. \& Picardeau, M. 2009. Leptospira: The dawn of the molecular genetics era for an emerging zoonotic pathogen. Nature Reviews: Microbiology 7(10): 736-747.

Laras, K., Van, C.B., Bounlu, K., Tien, N.T.K., Olson, J.G., Thongchanh, S. \& Corwin, A.L. 2002. The importance of leptospirosis in Southeast Asia. American Journal of Tropical Medicine and Hygiene 67(3): 278-286.

Lau, S.F., Wong, J.Y., Khor, K.H., Roslan, M.A., Abdul Rahman, M.S., Bejo, S.K., Radzi, R. \& Bahaman, A.R. 2017. Seroprevalence of leptospirosis in working dogs. Topics in Companion Animal Medicine 32(4): 121-125.

Levett, P.N. 2001. Leptospirosis. Clinical Microbiology 14(2): 296-326.

Miotto, B.A., Gil, A., Guilloux, A., Tozzi, B.F., Moreno, Z., Santana, A. \& Moreno, A.M. 2018. Prospective study of canine leptospirosis in shelter and stray dog populations: Identification of chronic carriers and different Leptospira species infecting dogs. PLOS ONE 13(7): e0200384.

Mylonakis, M.E., Bourtzi-Hatzopoulou, E., Koutinas, A.F., Petridou, E., Saridomichelakis, M.N., Leontides, L. \& Siochu, A. 2005. Leptospiral seroepidemiology in a feline hospital population in Greece. Veterinary Record 156(19): 615-616.

Ooteman, M.C., Vago, A.R. \& Koury, M.C. 2006. Evaluation of MAT, IgM ELISA and PCR methods for the diagnosis of human leptospirosis. Journal of Microbiological Methods 65(2): 247-257.

Pratt, N., Conan, A. \& Rajeev, S. 2017. Leptospira seroprevalence in domestic dogs and cats on the Caribbean Island of Saint Kitts. Veterinary Medicine International https://doi. org/10.1155/2017/5904757.

Rafizah, A.A.N., Aziah, B.D., Azwany, Y.N., Imran, M.K., Rusli, A.M., Nazri, S.M., Nikman, A.M., Nabilah, I., Asma, H.S., Zahiruddin, W.M. \& Zaliha, I. 2013. A hospital-based study on seroprevalence of leptospirosis among febrile cases in North Eastern Malaysia. International Journal of Infectious Diseases 17(6): 394-397.

Rodriguez, J., Blais, M.C., Lapointe, C., Arsenault, J., Carioto, L. \& Harel, J. 2014. Serologic and urinary PCR survey of leptospirosis in healthy cats and in cats with kidney disease. Journal of Veterinary Internal Medicine 28(2): 284-293.

Rojas, P., Monahan, A.M., Schuller, S. \& Miller, I.S. 2010. Detection and quantification of leptospires in urine of dogs: A maintenance host for the zoonotic disease leptospirosis. European Journal of Clinical Microbiology \& Infectious Diseases 29(10): 1305-1309.

Schuller, S., Francey, T., Hartmann, K., Hugonnard, M., Kohn, B., Nally, J.E. \& Sykes, J. 2015. European consensus statement on leptospirosis in dogs and cats. Journal of Small Animal Practice 56(3): 159-179.
Sessions, J.K. \& Greene, C.E. 2004. Canine leptospirosis: Epidemiology, pathogenesis, and diagnosis. Compendium on Continuing Education for the Practicing Veterinarian 26(8): 606-623.

Shafei, M.N., Sulong, M.R., Yaacob, N.A., Hassan, H., Wan Mohamad, W.M.Z., Daud. \& Abdullah, M.R. 2012. Seroprevalence of leptospirosis among town service workers in Northeastern State of Malaysia. International Journal of Collaborative Research on Internal Medicine \& Public Health 4(4): 395-403.

Sharma, M. \& Yodav, A.R. 2008. Leptospirosis: Epidemiology, diagnosis, and control. Journal of Infectious Disease and Antimicrobial Agents 25(2): 93-103.

Sykes, J.E., Hartmann, K., Lunn, K.F., Moore, G.E., Stoddard, R.A. \& Goldstein, R.E. 2011. 2010 ACVIM small animal consensus statement on leptospirosis: Diagnosis, epidemiology, treatment, and prevention. Journal of Veterinary Internal Medicine 25(1): 1-13.

Wasiński, B. \& Dutkiewicz, J. 2013. Leptospirosis-current risk factors connected with human activity and the environment. Annals of Agricultural and Environmental Medicine: AAEM 20(2): 239-244.

Weis, S., Rettinger, A., Bergmann, M., Llewellyn, J.R., Pantchev, N., Straubinger, R.K. \& Hartmann, K. 2017. Detection of Leptospira DNA in urine and presence of specific antibodies in outdoor cats in Germany. Journal of Feline Medicine and Surgery 19(4): 470-476.

Abdul Rahman Alashraf, Kuan Hua Khor, Rozanaliza Radzi, Soon Heng Goh \& Seng Fong Lau*

Department of Veterinary Clinical Studies

Faculty of Veterinary Medicine

Universiti Putra Malaysia

43400 UPM Serdang, Selangor Darul Ehsan

Malaysia

Siti Khairani-Bejo, Muhammad Sabri Abdul Rahman \& Muhammad Azri Roslan

Department of Veterinary Pathology and Microbiology

Faculty of Veterinary Medicine

Universiti Putra Malaysia

43400 UPM Serdang, Selangor Darul Ehsan

Malaysia

Puteri Azaziah Megat Abdul Rani

Department of Companion Animal Medicine and Surgery

Faculty of Veterinary Medicine

Universiti Putra Malaysia

43400 UPM Serdang, Selangor Darul Ehsan

Malaysia

Rosnah Ismail

Occupational Health Unit

Community Health Department

Universiti Kebangsaan Malaysia Medical Centre

Jalan Yaacob Latif, Bandar Tun Razak

56000 Cheras, Kuala Lumpur, Federal Territory

Malaysia

*Corresponding author; email: lausengfong@hotmail.com

Received: 6 March 2019

Accepted: 22 January 2020 